\title{
Nonfunctional adrenal incidentalomas may be related to bisphenol-A
}

\author{
Fatih Eker ${ }^{1} \cdot$ Askin Gungunes $^{2} \cdot$ Senay Durmaz ${ }^{2} \cdot$ Ucler Kisa $^{3} \cdot$ Zeynep Rumeysa Celik $^{3}$
}

Received: 15 March 2020 / Accepted: 14 September 2020 / Published online: 23 September 2020

(c) Springer Science+Business Media, LLC, part of Springer Nature 2020

\begin{abstract}
Purpose Bisphenol-A (BPA) is an endocrine-disrupting chemical that may affect the hormones and their receptors. The aim of this study is to determine whether BPA has an effect on the development of nonfunctional adrenal incidentaloma (NFAI). Methods Fifty patients who were admitted to endocrinology outpatient clinics and diagnosed as NFAI were included in the study. Fifty healthy people without adrenal mass and adrenal pathology in the upper abdominal computerized tomography or magnetic resonance imaging were also included as control group. Age, gender and body mass index of the study groups were similar. The serum samples for BPA were stored at $-80^{\circ} \mathrm{C}$ in refrigerator until working in the lab. Serum BPA levels were measured using ELISA technique.

Results Mean serum BPA level was $7.06 \pm 3.96 \mathrm{ng} / \mathrm{ml}$ in NFAI patients and $4.79 \pm 3.01 \mathrm{ng} / \mathrm{ml}$ in control group. Serum BPA level was significantly higher in NFAI group than control group $(p=0.001)$. Serum BPA levels were also found to be significantly higher in women with NFAI than in men with NFAI $(p=0.019)$.

Conclusions The mechanisms of NFAI development have not been clarified yet. Increased BPA exposure with developed industrialization may play a role in NFAI formation. For the reduction of BPA exposure, the use of plastic prepacked products, plastic containers, and safety measures are essential for public health.
\end{abstract}

Keywords Adrenal incidentaloma $\cdot$ Exposure $\cdot$ Bisphenol-A $\cdot$ Endocrine disrupter

\section{Introduction}

Endocrine disruptors are naturally occurring or man-made substances that can mimic or interfere with the endocrine system at certain doses [1]. Bisphenol-A (BPA), an endocrine-disrupting chemical (EDC), has capable of binding to both estrogen receptor $\alpha(E R \alpha)$ and estrogen receptor $\beta(\operatorname{ER} \beta)[2,3]$. BPA can generally be found in polyvinyl chloride (PVC) plastics, compact disc, thermal fax papers, paint, water, cola, fruit juice, milk bottles, plastic film covering the inner surface of beer cans and in

Askin Gungunes

askn79@yahoo.com

1 Department of Internal Medicine, Çanakkale Yenice State Hospital, Çanakkale, Turkey

2 Department of Endocrinology and Metabolic Diseases, Kirikkale University, School of Medicine, Kirikkale, Turkey

3 Department of Biochemistry, Kirikkale University, School of Medicine, Kirikkale, Turkey baby bottle [4]. In addition, plastic containers used for storing food and beverages, the inner surfaces of tin cans, dental fillings, toys, clothes, and even household dust are known to be places where BPA is detected [5]. Generally, the food products are considered the main source of BPA exposure. But, many studies have shown that BPA is transferred from polycarbonate baby bottles and reusable polycarbonate water bottles to the liquids contained in the bottles [5, 6]. BPA production which is increased by industrialization, leads to more BPA exposure. Increased BPA levels can cause cancer, birth defects, reproductive, immune, developmental and other organ disorders in humans and other animals [1]. Increased BPA levels in postmenopausal women have been associated with increased inflammation and oxidative stress. Reduced semen quality and sperm DNA damage have been reported to related with increased BPA levels as well as ovarian dysfunction [7]. One study reported high levels of BPA in patients with obese and polycystic ovary syndrome [8].

There is only a few knowledge about exposure to BPA on the adrenal gland [9]. In one study, BPA-containing food $(25 \mathrm{mg} / \mathrm{kg}$ ) was given to pregnant rats until the end of 
pregnancy, and BPA was found to increase adrenal gland weight in both male and female offspring [10]. Prenatal exposure to BPA has been shown to cause high plasma corticosterone levels by increasing dose-dependent levels of steroidogenic acute regulatory protein (StAR) in adult female mouse offspring. BPA has been shown to increase StAR protein levels through an unknown mechanism [9].

Adrenal incidentaloma refers to incidentally detected adrenal masses during radiological examinations or abdominal surgical procedures in patients without any symptoms or signs suggestive of adrenal mass [11, 12]. The widespread use of noninvasive imaging methods has increased the incidentally detected adrenal masses [13]. While the prevalence of nonfunctional adrenal incidentaloma (NFAI) is $1-8.7 \%$ in autopsy series, it reaches to $10 \%$ especially in elderly population. NAFIs are mostly benign and non-functional. Non-hormone-releasing benign adrenal incidentalomas usually do not require surgery. Rarely, fatal adrenal cancer or metastasis can potentially developed. Functional adrenal incidentalomas as Cushing's syndrome, pheochromocytoma, primary hyperaldosteronismless frequently observed [14, 15]. It is important to distinguish between benign and malign masses or between functional and non-functional masses.

According to our knowledge, there is no study to investigate BPA levels in patients with NFAI in the literature. The aim of our study is to determine whether there is a relationship between serum BPA levels and NFAI.

\section{Materials and methods}

Fifty patients who admitted to the our endocrinology outpatient clinic between January 2018 and December 2018 and followed up with the diagnosis of NFAI were included in the study. Fifty age- and sex-matched healthy subjects with no adrenal mass or adrenal pathology on the upper abdomen CT or MRI were included in the control group.

Written informed consent was obtained from all participants.

Ethics committee approval was obtained from Kirikkale University School of Medicine ethics committee on 06.03.2018 with the decision number 04/01.

Patients over 18 years old with nonfunctional adrenal mass were included in the study.

Patients with diabetes mellitus, thyroid dysfunction, acute or chronic infection, malignancy, coronary artery disease, renal failure, liver failure, pregnancy, a history of drug use affecting surrenal functions, insulin resistance, antidepressants, antipsychotics or antiepileptics, use of alcohol, smoking, a history of rheumatology illness were excluded from the study.
The blood samples for fasting plasma glucose, fasting insulin and serum BPA levels between 08.30-10.00 AM (Ante Meridiem) were collected from the participants after fasting period at least $8 \mathrm{~h}$. All blood samples were centrifuged at $4000 \mathrm{rpm}$ for $10 \mathrm{~min}$ and their serum were separated and stored at $-80^{\circ} \mathrm{C}$ until working in the lab.

\section{Anthropometric measurements}

Height was measured with a standard height scale without hats and shoes. During the measurement, accessories (such as coats, shoes) were removed. Body weight and fat distributions were measured by bioelectrical impedance analysis TANITA. Fat percentage (\%), fat mass (kg), lean mass $(\mathrm{kg})$ were measured by using TANITA.

The systolic and diastolic blood pressure were measured with a sphingomanometer from the left arm (F.Bosch Medizintech brand) after resting the patient in a sitting position for half an hour.

\section{Adopted criteria to define NFAI}

\section{Radiological imaging}

The size and imaging features of the adrenal mass are very important in determining whether the adrenal mass is benign or malignant. The probability of adrenal masses larger than $4 \mathrm{~cm}$ to be malignant increases significantly [16]. Initially, noncontrast (unenhanced) CT images were obtained as a baseline. Subsequently, postcontrast and delayed contrast-enhanced CT images were obtained. Hounsfield unit (HU) scale is a quantitative method for describing radiodensity. Radiograph attenuation was measured semiquantitatively with the Hounsfield scale in unenhanced CT. Intracytoplasmic fat in adenomas causes low attenuation on unenhanced CT, while non-adenoma masses have higher attenuation. If $\mathrm{HU}<10$ on unenhanced CT, it is very likely to be adenoma. However, up to $30 \%$ of adenomas are not lipid-rich and cannot be distinguished from non-adenoma masses in unenhanced CT scans [17].

According to delayed contrast-enhanced CT images, absolute contrast washout rate was calculated. Adenomas typically shows rapid contrast washout on delayed contrastenhanced CT. Ten minutes after the contrast administration, having more than $50 \%$ contrast agent wash out in the mass is $100 \%$ sensitive and specific for adenoma $[18,19]$.

Although the preferred imaging method for evaluating the adrenal gland is CT, MRI can be performed in some patients due to some clinical advantages, such as the absence of radiation exposure. $\mathrm{T} 1$ and $\mathrm{T} 2$ weighted imaging can help in benign malignant separation, moreover, MR with chemical shift imaging method can be used for this purpose [20]. 


\section{Endocrine tests for adrenal hyperfunction}

All patients diagnosed with adrenal incidentaloma were evaluated with endocrine tests for three adrenal hyperfunction forms (Subclinical Cushing's syndrome, pheochromocytoma, primary hyperaldosteronism).

To exclude subclinical Cushing syndrome, baseline serum dehydroepiandrosterone sulfate (DHEAS) level was measured and overnight $1 \mathrm{mg}$ of dexamethasone suppression test (DST) was performed. Low DHEAS is important in that it reflects chronic suppression of ACTH secretion. $1 \mathrm{mg}$ dexamethasone is administered orally between $11 \mathrm{PM}$ (Post Meridiem) - 12 PM and blood samples were taken for serum cortisol levels the next morning between 8 and 9 AM. The value of $1.8 \mathrm{mcg} / \mathrm{dl}(50 \mathrm{nmol} / \mathrm{l})$ was chosen as cutoff because it significantly increased diagnostic sensitivity $[21,22]$ and autonomous cortisol production was excluded in patients with serum cortisol below $1.8 \mathrm{mcg} / \mathrm{dl}$.

To exclude pheochromocytoma, 24-h urinary fractionated metanephrines [23] and valin mandelic acid levels were measured. If clinical suspicion is low in patients with normal results, no further tests were performed. In patients with high clinical suspicion and spells, a urine sample was collected during the spell and the test was repeated, and if normal, the diagnosis of pheochromocytoma was excluded.

In patients with adrenal incidentaloma with hypertension, plasma aldosterone (ng/dl) / renin (ng/ml/hour) ratio was examined to exclude primary aldosteronism [24], and if the ratio was greater than 20 , confirmation tests were performed. On the other hand, no further investigation was performed in patients with a ratio below 20 .

The exclusion of adrenal hyperfunctional forms (subclinical Cushing's syndrome, pheochromocytoma, primary hyperaldosteronism) according to the results of the above endocrine tests, and also the features compatible with adenoma according to size and radiological imaging characteristics were defined as NAFI.

\section{Laboratory analysis}

Serum BPA levels were measured with the MyBiosource General Bisphenol A ELISA Kit. (MyBiosource, Inc. San Diego, USA). Serum samples were incubated at $37^{\circ} \mathrm{C}$ for $90 \mathrm{~min}$. The layers were washed, working solution with biotinylated antibody was added and incubated at $37^{\circ} \mathrm{C}$ for $60 \mathrm{~min}$. After three washes, the enzyme solution was added and incubated for $30 \mathrm{~min}$ at $37^{\circ} \mathrm{C}$. After washing five times, color reagent solution was allowed to stand at $37^{\circ} \mathrm{C}$ for 30 min and color reagent $\mathrm{C}$ was added.

The standard BPA detection range of the BPA kit used in the study was $200-3.12 \mathrm{ng} / \mathrm{ml}$ and had a minimum detectable serum BPA level of up to $0.6 \mathrm{ng} / \mathrm{ml}$. Intra-test sensitivity is $88 \%$ and inter-test sensitivity is $\leq 12 \%$. BPA values were calculated from the absorbances obtained by plotting the graph curve according to the standards.

The Homeostatic Model Assessment Insulin Resistance (HOMA-IR) index was calculated from records for each patient using the formula as [fasting plasma insulin ( $\mu \mathrm{IU} /$ ml) X fasting plasma glucose (mmol/l)/22.5], and HOMAIR $\geq 2.7$ were considered insulin resistance [25].

\section{Statistical methods}

In the statistical analysis of this study, Statistical Package for the Social Science (SPSS 20) program was used. The significance limit value was taken as $p<0.05$. Descriptive statistics are expressed as mean \pm standard deviation for numerical variables and as numbers and percentages for nominal variables. In numerical data without normal distribution, median (IQR) was used. In order to investigate the normal distribution of numerical variables, Kolmogorov-Smirnov and Shapiro-Wilks tests were used. In comparison of two independent groups for a numerical variable, $t$-test (Student's $t$ test) in independent groups and Mann-Whitney- $U$ test were used in normal groups according to whether they fit to normal distribution or not. Chi-square test was used to compare nominal variables between groups. Spearman's correlation analysis was used to investigate the relationship between two numerical variables. Logistic regression analysis was performed with variables with statistically significant results and $p$ values less than 0.25 [26].

\section{Results}

\section{Demographic characteristics}

Fifty patients with NFAI and 50 healthy volunteers participated in our study. $70.0 \%(n=35)$ of the 50 individuals in the NFAI group were female and $30.0 \%(n=15)$ were male. $64 \%(n=32)$ of the 50 subjects in the healthy control group were female and $36 \%(n=18)$ were male. There were no statistically significant difference between the two groups in terms of gender $(p=0.523)$ and age $(51.9 \pm 8.5$ years vs. $49.6 \pm 11.3$ years, respectively, $p=0.252$ ).

\section{Anthropometric characteristics and blood pressure profile}

(a) Mean body mass index (BMI) was $31.6 \pm 5.7 \mathrm{~kg} / \mathrm{m}^{2}$ in the patient group and $30.7 \pm 4.9 \mathrm{~kg} / \mathrm{m}^{2}$ in the control group. The mean fat percentage was $33.0 \pm 8.3 \%$ in the patient group and $31.7 \pm 8.3 \%$ in the control group. The mean fat mass was $27.4 \pm 9.7 \mathrm{~kg}$ in the 
patient group and the mean fat mass in the control group was $27.6 \pm 9.6 \mathrm{~kg}$. The mean lean mass was $49.8 \pm 8.4 \mathrm{~kg}$ in the patient group and the mean lean mass in the control group was $48.4 \pm 10.1 \mathrm{~kg}$. There were no statistically significant difference between the two groups in terms of BMI $(p=0.642)$, fat percentage $(p=0.414)$, fat mass $(p=0.699)$ and lean mass $(p=0.530)$.

(b) The mean systolic blood pressure was $127.7 \pm$ $8.7 \mathrm{mmHg}$ in the NFAI group and $129.1 \pm 6.9 \mathrm{mmHg}$ in the control group. The mean diastolic blood pressure was $79.6 \pm 4.8 \mathrm{mmHg}$ in the NFAI group and $79.9 \pm 4.4 \mathrm{mmHg}$ in the control group. There were no statistically significant difference between the groups in terms of systolic blood pressure $(p=0.584)$ and diastolic blood pressure $(p=0.967)$.

\section{Serum BPA levels of the study population}

The serum BPA levels were $7.06 \pm 3.96 \mathrm{ng} / \mathrm{ml}$ in patients with NFAI and $4.79 \pm 3.01 \mathrm{ng} / \mathrm{ml}$ in control group. The mean BPA level in NFAI group was higher than their control group $(p=0.001)$. Table 1 shows the serum BPA levels of study population.

Serum BPA levels in women were significantly higher than men in NFAI group $(7.9 \pm 4.2$ vs. $5.0 \pm 2.3 \mathrm{ng} / \mathrm{ml}, p=$ $0.019)$. On the other hand, there was no significant difference in BPA values of patients with $\mathrm{BMI}<30$ and $\mathrm{BMI} \geq$ 30 in the NFAI group $(6.6 \pm 3.2$ vs. $7.3 \pm 4.4 \mathrm{ng} / \mathrm{ml}, p=$ 0.768 , respectively).

\section{Characteristics of adrenal adenoma in NFAl group}

In abdominal CT or MRI, $56 \%(n=28)$ of the NFAIs were located in the left adrenal gland, $34 \%(n=17)$ in the right adrenal gland, and $10 \%(n=5)$ were bilaterally. The mean adenoma size was $18.4 \pm 6.8 \mathrm{~mm}$. The average $\mathrm{HU}$ was $3.02 \pm 15.13$. The mean BPA level in adenomas located left adrenal gland was $7.16 \pm 3.29 \mathrm{ng} / \mathrm{ml}$, the mean BPA level in adenomas located in the right adrenal gland was $6.30 \pm$ $3.20 \mathrm{ng} / \mathrm{ml}$ and the mean BPA level in bilateral adrenal adenomas was $9.07 \pm 8.44 \mathrm{ng} / \mathrm{ml}$. No statistically significant differences were found between BPA levels by location

Table 1 Serum BPA levels of the study groups

\begin{tabular}{llll}
\hline & $\begin{array}{l}\text { NFAI group } \\
(n=50)\end{array}$ & $\begin{array}{l}\text { Control group } \\
(n=50)\end{array}$ & $p$ value* \\
\hline BPA $(\mathrm{ng} / \mathrm{ml})$ & $7.06 \pm 3.96$ & $4.79 \pm 3.01$ & 0.001 \\
\hline
\end{tabular}

${ }^{*} p<0.05$ was statistically significance $(p=0.552)$. Table 2 shows adenoma characteristics of patients with NFAI.

\section{The results of fasting plasma glucose, fasting plasma insulin, and HOMA-IR}

In the NFAI group, the mean fasting plasma glucose was $99.1 \pm 13.8 \mathrm{mg} / \mathrm{dl}$, the mean fasting plasma insulin was $12.6 \pm 7.5 \mu \mathrm{IU} / \mathrm{ml}$ and HOMA-IR was $3.08 \pm 1.77$. In the control group, the mean fasting plasma glucose was $89.3 \pm$ $7.8 \mathrm{mg} / \mathrm{dl}$, the mean fasting plasma insulin was $9.9 \pm$ $4.2 \mu \mathrm{IU} / \mathrm{ml}$ and HOMA-IR was $2.19 \pm 0.94$. Fasting plasma glucose $(p<0.001)$ and HOMA-IR $(p=0.007)$ values were significantly higher in the NFAI group than their control subjects. There was no statistically significant difference between the patient and control groups in terms of fasting plasma insulin levels ( $p=0.087$ ) (Table 3).

According to HOMA-IR values, it was found that $58 \%$ $(n=29)$ of 50 patients had insulin resistance and $42 \%(n=$ 21) did not have insulin resistance. Mean adenoma size of patients without insulin resistance was $16.1 \pm 5.7 \mathrm{~mm}$. The mean adenoma size of patients with insulin resistance was $19.1 \pm 7.5 \mathrm{~mm}$. There was no statistically significant difference between patients with and without insulin resistance in terms of adenoma size $(p=0.234)$. The mean BPA of patients without insulin resistance was $7.46 \pm 3.28 \mathrm{ng} / \mathrm{ml}$ and the mean BPA of patients with insulin resistance was $6.77 \pm 4.43 \mathrm{ng} / \mathrm{ml}$. There was no statistically significant difference between patients with and without insulin resistance in terms of BPA $(p=0.302)$. Table 4 shows the adenoma size and BPA values according to the insulin resistance status in the NFAI group.

\section{Correlation analysis}

There were not statistically significant correlation between age, fat percentage, fat mass, lean mass and BPA levels in patients with NFAI and control group.

No statistically significant correlations were found among with BPA and adenoma size and HU in the patients with NFAI. There were not significant correlations between

Table 2 Characteristics of adrenal adenoma in NFAI group

\begin{tabular}{ll}
\hline Adenoma placement $^{\mathrm{a}}$ & $\%(n)$ \\
\hline Left adrenal placement & $\% 56(n=28)$ \\
Right adrenal placement & $\% 34(n=17)$ \\
Bilateral adrenal placement & $\% 10(n=5)$ \\
Adenoma size (mm) & \\
$\mathrm{HU}^{\mathrm{a}}$ & $18.4 \pm 6.8$ \\
\hline
\end{tabular}

${ }^{a}$ Numerical variables were expressed as mean \pm standard deviation, categorical variables were expressed as percentage and frequency 
Table 3 Fasting plasma glucose, fasting plasma insulin and HOMA-IR results of the study groups

Table 4 Adenoma size and BPA values according to the insulin resistance status in the NFAI group

Table 5 The results of logistic regression analysis ${ }^{\mathrm{a}}$

\begin{tabular}{llcr}
\hline & NFAI group $(n=50)^{\mathrm{a}}$ & ${\text { Control group }(n=50)^{\mathrm{a}}}$ & $p$ value* \\
\hline Fasting plasma glucose $(\mathrm{mg} / \mathrm{dl})$ & $99.1 \pm 13.8$ & $89.3 \pm 7.8$ & $<0.001$ \\
Fasting plasma insulin $(\mu \mathrm{IU} / \mathrm{ml})$ & $12.6 \pm 7.5$ & $9.9 \pm 4.2$ & 0.087 \\
HOMA-IR & $3.08 \pm 1.77$ & $2.19 \pm 0.94$ & 0.007 \\
\hline
\end{tabular}

${ }^{*} p<0.05$ was statistically significance

${ }^{\mathrm{a}}$ Mean \pm standard deviation

\begin{tabular}{lllc}
\hline & $\begin{array}{l}\text { Patients without insulin resistance } \\
(n=21)^{\mathrm{a}}\end{array}$ & $\begin{array}{l}\text { Patients with insulin resistance } \\
(n=29)^{\mathrm{a}}\end{array}$ & $p$ value* \\
\hline Adenoma size $(\mathrm{mm})$ & $16.1 \pm 5.7$ & $19.1 \pm 7.5$ & 0.234 \\
BPA $(\mathrm{ng} / \mathrm{ml})$ & $7.46 \pm 3.28$ & $6.77 \pm 4.43$ & 0.302 \\
\hline
\end{tabular}

$* p<0.05$ was statistically significance

${ }^{\mathrm{a}}$ Mean \pm standard deviation

\begin{tabular}{llllll}
\hline Independent variables $^{\mathrm{b}}$ & \multicolumn{2}{l}{ Univariate } & & \multicolumn{2}{l}{ Multivariate } \\
\cline { 2 - 3 } \cline { 6 - 6 } & $\begin{array}{l}\mathrm{RR}^{\mathrm{c}}(95 \% \text { Confidence } \\
\text { Interval }\end{array}$ & $p$ value & & $\begin{array}{l}\mathrm{RR}^{\mathrm{c}}(95 \% \text { Confidence } \\
\text { Interval })\end{array}$ & $p$ value \\
\hline BPA & $1.23(1.07-1.42)$ & 0.003 & & $1.24(1.07-1.45)$ & 0.004 \\
HOMA-IR & $1.65(1.16-2.36)$ & 0.005 & & $1.63(1.10-2.43)$ & 0.014 \\
HDL Cholesterol & $0.97(0.94-1.01)$ & 0.179 & & $0.98(0.94-1.02)$ & 0.411 \\
Creatine & $0.67(0.05-8.20)$ & 0.755 & & $0.69(0.04-11.8)$ & 0.802 \\
AST & $1.00(0.96-1.04)$ & 0.821 & & $0.98(0.93-1.03)$ & 0.614 \\
\hline
\end{tabular}

${ }^{\mathrm{a}}$ The dependent variable is the presence of adenoma. 0: no adenoma, 1: adenoma exists

${ }^{\mathrm{b}}$ The variables with $p<0.25$ were included in the model in patient and control comparisons (fasting plasma glucose and fasting insulin values were not included in the model because they were included in the HOMAIR formula)

${ }^{\mathrm{c}}$ Relative risk
BPA and fasting plasma glucose, fasting insulin and HOMA-IR.

According to logistic regression in univariate analysis elevated serum BPA level was increase adenoma risk by 1.23 fold [RR: 1.23 (1.07-1.42); $p=0.003$ ], and elevated HOMA-IR was increase adenoma risk by 1.65 times [RR: 1.65 (1.16-2.36); $p=0.005]$; in addition, high BPA was increase adenoma risk by 1.24 times [RR: 1.24 (1.07-1.45); $p=0.004]$, and high HOMA-IR was increase adenoma risk by 1.63 times [RR: $1.63(1.10-2.43) ; p=0.014]$ in multivariate analysis. Table 5 shows the results of logistic regression analysis.

\section{BPA exposure of the patient and control group, subgroup analysis}

We prepared a questionnaire form based on the work of Nomura et al. (1) [27] to examine BPA exposure of the patient and control group. 20 participants from the patient group and 20 participants from the control group were examined in this respect. Questions were asked to the participants in both groups about canned meals, plasticpackaged food, beverages in cans, beverages in plastic, water in plastic containers, microwave meals, meals at restaurants, fast food consumption and frequency, and the answers were compared. No significant difference was found between the patient and control groups $(p>0.05)$ (Table 6). In addition, the participants were asked whether the products consumed pay attention to whether they contain BPA or not, and it was observed that both the patient and the control group did not pay attention to the BPA content of the products consumed (Table 6).

\section{Discussion}

According to our knowledge, we firstly demonstrated that serum BPA levels in patients with NFAI were significantly higher than in healthy controls in our study. To date, there has been no study on serum BPA levels in patients with NFAI in the medical literature. BPA is an organic compound that disrupts endocrine and neuroendocrine systems 
Table 6 Comparison of the NAFI and control group in terms of BPA exposure
NAFI groups Control groups $P$ value

$(n=20) \quad(n=20)$

\begin{tabular}{|c|c|c|c|}
\hline \multicolumn{4}{|l|}{ Canned meals } \\
\hline Monthly & 12 & 13 & \multirow[t]{3}{*}{0.403} \\
\hline 1 time/Week & 6 & 6 & \\
\hline 2-4 time/Week & 2 & 1 & \\
\hline \multicolumn{4}{|c|}{ Plastic-packaged food } \\
\hline Monthly & 5 & 3 & \multirow[t]{3}{*}{0.154} \\
\hline 1 time/Week & 13 & 12 & \\
\hline 2-4 time/Week & 2 & 5 & \\
\hline \multicolumn{4}{|l|}{ Microwave meals } \\
\hline Monthly & 17 & 17 & \multirow[t]{3}{*}{0.452} \\
\hline 1 time/Week & 1 & 2 & \\
\hline$>5$ time/Week & 2 & 1 & \\
\hline \multicolumn{4}{|l|}{ Beverages in cans } \\
\hline Monthly & 7 & 6 & \multirow[t]{3}{*}{0.404} \\
\hline 1 time/Week & 11 & 11 & \\
\hline 2-4 time/Week & 2 & 3 & \\
\hline \multicolumn{4}{|l|}{ Beverages in plastic } \\
\hline Monthly & 8 & 7 & \multirow[t]{4}{*}{0.500} \\
\hline 1 time/Week & 8 & 10 & \\
\hline 2-4 time/Week & 3 & 3 & \\
\hline$>5$ time/Week & 1 & 0 & \\
\hline \multicolumn{4}{|c|}{ Water in plastic containers } \\
\hline Monthly & 3 & 4 & \multirow[t]{3}{*}{0.424} \\
\hline 1 time/Week & 1 & 1 & \\
\hline$>5$ time/Week & 16 & 15 & \\
\hline \multicolumn{4}{|l|}{ Meals at restaurants } \\
\hline Monthly & 16 & 13 & \multirow[t]{2}{*}{0.240} \\
\hline 1 time/Week & 4 & 7 & \\
\hline \multicolumn{4}{|l|}{ Fast food } \\
\hline Monthly & 17 & 14 & \multirow[t]{3}{*}{0.378} \\
\hline 1 time/Week & 2 & 6 & \\
\hline 2-4 time/Week & 1 & 0 & \\
\hline \multicolumn{4}{|l|}{ Attention to BPA } \\
\hline Yes & 0 & 0 & \multirow{2}{*}{$\begin{array}{l}\text { No statistics are computed because } \\
\text { attention to BPA is a constant }\end{array}$} \\
\hline No & 20 & 20 & \\
\hline
\end{tabular}

Fisher Freeman Halton test was used by affecting various hormones and hormone receptors $[28,29]$. We consider that high serum BPA level may associate with development of NFAI, because it has been previously reported that BPA may affect gene expression and increase sensitivity to neoplastic transformations in experimental studies [10, 28, 30].

The factors affecting the development of NAFI are not well understood yet. In a previous study, it was reported that BPA disrupts the hypothalamus-pituitary-adrenal axis [28]. On the other hand, limited experimental studies have been conducted on the effects of BPA levels on adrenal tissue.
Medwid et al. were tried to determine whether prenatal exposure to BPA would alter adrenal steroid synthesis in adult mouse offspring. Pregnant rats were fed food containing BPA at a dose of $25 \mathrm{mg} / \mathrm{kg}$ until the end of pregnancy, then the adrenal glands of the mice were examined. They found that the exposure of BPA was associated with increase of weight of adrenal gland and high plasma corticosterone levels in both male and female mice, but plasma ACTH levels were not different between groups [10].

In another previously study, exposure to prenatal BPA in mouse offspring has been shown to increase levels of the 
steroidogenic acute regulatory protein, which is the ratelimiting step in steroid synthesis, and also lead to associated high plasma corticosterone levels. There was also reported that BPA increased StAR protein levels in a dose-dependent manner [9]. BPA has been shown to increase StAR protein levels through an unknown mechanism independent of StAR gene transcription, translation and/or half-life. In the same study, no difference was found between the protein

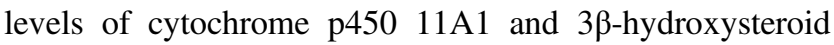
dehydrogenase enzymes [9]. In addition, Medwid et al. also demonstrated that BPA stimulated adrenal cell proliferation via $E R \beta$ and Shh signaling pathway which may promotes cell proliferation by directly activating the proliferation factors cyclin D1 and cyclin D2 [31].

On the other hand, in animal studies examining the effects of carbohydrate metabolism of BPA, increased insulin content in $\beta$ cells was observed in male mice exposed to $100 \mathrm{mcg} / \mathrm{kg}$ of BPA for four days. Impaired glucose tolerance was observed when these mice underwent glucose tolerance test [32]. In our study, no significant correlation was found between serum BPA levels and fasting plasma glucose and HOMA-IR levels and there were no patients diagnosed with diabetes. However, our patients with NFAI had significantly increased fasting plasma glucose levels and increased HOMA-IR levels compared to the control group. Moreover, there were more prediabetic patients in the NFAI group than in control group. Increased fasting plasma glucose and increased HOMA-IR levels may be associated with NFAI. Ermetici et al. reported that the increase in proinflammatory cytokines such as TNF- $\alpha$, IL- 6 , monocyte chemoattractant protein-1 may cause subclinical inflammation that associated with insulin resistance and metabolic syndrome in patients with NFAI [33]. Further studies are needed on this subject. In vitro studies have shown that BPA may causes obesity. BPA has been shown to stimulate adipocyte differentiation by stimulating adipogenic transcription factors, thereby increasing lipid accumulation [34]. In another study, generalized obesity, abdominal obesity and insulin resistance prevalence was found higher in individuals with high urinary BPH [35]. In our study, both of NFAI group and control group had similar BMI and body fat distribution parameters. Moreover, we didnot found any correlations among with serum BPA, BMI and fasting insulin levels.

Different analytical techniques have been used to measure conjugated BPA concentrations in human serum [36]. The gas chromatography-mass spectrometry, high performance liquid chromatography and ELISA are considered reliable methods to measure trace levels of BPA in biological samples [36]. In our study, we used ELISA method for the measurement of serum BPA.

Our study has some limitations, firstly, we could not measure BPA in direct adrenal tissue samples. Another limitation is that we do not know exactly how often our patients use polycarbonate plastic containers as eating, drinking and storage containers and how much they are exposed to BPAcontaining products. We prepared a questionnaire form to examine BPA exposure of the patient and control group. However, we could not reach a significant part of the participants from the patient and control groups due to the COVID 19 pandemic. We were not able to directly measure BPA levels in drinks and foods consumed. On the other hand, where our study has been conducted is an industrial area. Factories related to oil refinery and defense industry are localized in this area, so we think that exposure may occur through other ways we cannot measure, such as breathing air. As the third, BPA levels were measured cross-sectionally in our study, but it would be better to use the mean values by making serial measurements.

As a conclusion, the mechanisms of NFAI development have not been fully elucidated yet, and increasing BPA exposure with developing industrialization may be important in NFAI subjects. In order to reduce BPA exposure, limiting the use of plastic prepackaged products, plastic containers and taking safety precautions are necessary for public health.

\section{Compliance with ethical standards}

Conflict of interest The authors declare that they have no conflict of interest.

Ethical approval All procedures performed were in accordance with the ethical standards of the institutional and/or national research committee and with the 1964 Helsinki declaration and its later amendments or comparable ethical standards. Ethics committee approval was obtained from Kirikkale University School of Medicine ethics committee on 06.03.2018 with the decision number 04/01.

Consent to participate Informed consent was obtained from all individual participants included in the study.

Consent for publication Consent was obtained from participants about publishing their data.

Publisher's note Springer Nature remains neutral with regard to jurisdictional claims in published maps and institutional affiliations.

\section{References}

1. O. Kuzukiran, B. Yurdakok-Dikmen, S. Sevin, U.T. Sireli, G. Iplikcioglu-Cil, A. Filazi, Determination of selected endocrine disruptors in organic, free-range, and battery-produced hen eggs and risk assessment. Environ. Sci. Pollut. Res. Int. 25(35), 35376-35386 (2018)

2. I.A. Lang, T.S. Galloway, A. Scarlett, W.E. Henley, M. Depledge, R.B. Wallace, D. Melzer, Association of urinary bisphenol A concentration with medical disorders and laboratory abnormalities in adults. JAMA 300(11), 1303-1310 (2008)

3. J.C. Gould, L.S. Leonard, S.C. Maness, B.L. Wagner, K. Conner, T. Zacharewski, S. Safe, D.P. McDonnell, K.W. Gaido, Bisphenol 
A interacts with the estrogen receptor $\alpha$ in a distinct manner from estradiol. Mol. Cell Endocrinol. 142(1-2), 203-214 (1998)

4. C.A. Staples, P.B. Dorn, G.M. Klecka, S.T. O'Block, L.R. Harris, A review of the environmental fate, effects, and exposures of bisphenol A. Chemosphere 36(10), 2149-2173 (1998)

5. H.H. Le, E.M. Carlson, J.P. Chua, S.M. Belcher, Bisphenol A is released from polycarbonate drinking bottles and mimics the neurotoxic actions of estrogen in developing cerebellar neurons. Toxicol. Lett. 176(2), 149-156 (2008)

6. L.N. Vandenberg, R. Hauser, M. Marcus, N. Olea, W.V. Welshons, Human exposure to bisphenol A (BPA). Reprod. Toxicol. 24(2), 139-177 (2007)

7. B.S. Rubin, Bisphenol A: an endocrine disruptor with widespread exposure and multiple effects. J. Steroid Biochem Mol. Biol. 127 (1-2), 27-34 (2011)

8. T. Takeuchi, O. Tsutsumi, Y. Ikezuki, Y. Takai, Y. Taketani, Positive relationship between androgen and the endocrine disruptor, bisphenol $\mathrm{A}$, in normal women and women with ovarian dysfunction. Endocr. J. 51(2), 165-169 (2004)

9. S. Medwid, H. Guan, K. Yang, Bisphenol A stimulates steroidogenic acute regulatory protein expression via an unknown mechanism in adrenal cortical cells. J. Cell Biochem 120(2), 2429-2438 (2019)

10. S. Medwid, H. Guan, K. Yang, Prenatal exposure to bisphenol A disrupts adrenal steroidogenesis in adult mouse offspring. Environ. Toxicol. Pharm. 43, 203-208 (2016)

11. M.M. Grumbach, B.M. Biller, G.D. Braunstein, K.K. Campbell, J. A. Carney, P.A. Godley, E.L. Harris, J.K. Lee, Y.C. Oertel, M.C. Posner, J.A. Schlechte, H.S. Wieand, Management of the clinically inapparent adrenal mass (incidentaloma). Ann. Intern. Med. 138(5), 424-429 (2003)

12. G. Mansmann, J. Lau, E. Balk, M. Rothberg, Y. Miyachi, S.R. Bornstein, The clinically inapparent adrenal mass: update in diagnosis and management. EndocrRev 25(2), 309-340 (2004)

13. -Adrenal ve Gonadal Hastalıklar Çalışma Grubu.: Türkiye Endokrinoloji ve Metabolizma Derneği, Adrenal ve Gonadal Hastalıklar Kılavuzu, 12. Baskı, Ankara (2018)

14. L. Barzon, C. Scaroni, N. Sonino, F. Fallo, M. Gregianin, C. Macrì, M. Boscaro, Incidentally discovered adrenal tumors: endocrine and scintigraphic correlates. J. Clin. Endocrinol. Metab. 83(1), 55-62 (1998)

15. A.A. Kasperlik-Zeluska, E. Rosłonowska, J. Słowinska-Srzednicka, B. Migdalska, W. Jeske, A. Makowska, H. Snochowska, Incidentally discovered adrenal mass (incidentaloma): investigation and management of 208 patients. Clin. Endocrinol. 46(1), 29-37 (1997)

16. A. Angeli, G. Osella, A. Alì, M. Terzolo, Adrenal incidentaloma: an overview of clinical and epidemiological data from the National Italian Study Group. Horm. Res. 47, 279-283 (1997)

17. A.H. Hamrahian, A.G. Ioachimescu, E.M. Remer, G. MottaRamirez, H. Bogabathina, H.S. Levin, S. Reddy, I.S. Gill, A. Siperstein, BravoEL, Clinical utility of noncontrast computed tomography attenuation value (hounsfield units) to differentiate adrenal adenomas/hyperplasia from nonadenomas: Cleveland Clinic experience. J. Clin. Endocrinol. Metab. 90(2), 871-877 (2005)

18. D.H. Szolar, M. Korobkin, P. Reittner, A. Berghold, T. Bauernhofer, H. Trummer, H. Schoellnast, K.W. Preidler, H. Samonigg, Adrenocortical carcinomas and adrenal pheochromocytomas: mass and enhancement loss evaluation at delayed contrastenhanced CT. Radiology 234(2), 479-485 (2005)

19. C.S. Peña, G.W. Boland, P.F. Hahn, M.J. Lee, P.R. Mueller, Characterization of indeterminate (lipid-poor) adrenal masses: use of washout characteristics at contrast-enhanced CT. Radiology 217(3), 798-802 (2000)

20. I. Platzek, D. Sieron, V. Plodeck, A. Borkowetz, M. Laniado, R.T. Hoffmann, Chemical shift imaging for evaluation of adrenal masses: a systematic review and meta-analysis. Eur. Radio. 29(2), 806-817 (2019)
21. L.K. Nieman, B.M. Biller, J.W. Findling, J. Newell-Price, M.O. Savage, P.M. Stewart, V.M. Montori, The diagnosis of Cushing's syndrome: an Endocrine Society Clinical Practice Guideline. J. Clin. Endocrinol. Metab. 93(5), 1526-1540 (2008)

22. F. Ceccato, M. Barbot, M. Zilio, A.C. Frigo, N. Albiger, V. Camozzi, G. Antonelli, M. Plebani, F. Mantero, M. Boscaro, C. Scaroni, Screening tests for cushing's syndrome: urinary free cortisol role measured by LC-MS/MS. J. Clin. Endocrinol. Metab. 100(10), 3856-3861 (2015)

23. J.W. Lenders, Q.Y. Duh, G. Eisenhofer, A.P. Gimenez-Roqueplo, S.K. Grebe, M.H. Murad, M. Naruse, K. Pacak, W.F. Young Jr, Pheochromocytoma and paraganglioma: an endocrine society clinical practice guideline. J. Clin. Endocrinol. Metab. 99(6), 1915-1942 (2014)

24. J.W. Funder, R.M. Carey, F. Mantero, M.H. Murad, M. Reincke, H. Shibata, M. Stowasser, W.F. Young Jr, The management of primary aldosteronism: case detection, diagnosis, and treatment: an Endocrine Society Clinical Practice Guideline. J. Clin. Endocrinol. Metab. 101(5), 1889-1916 (2016)

25. D.R. Matthews, J.P. Hosker, A.S. Rudenski, B.A. Naylor, D.F. Treacher, R.C. Turner, Homeostasis model assessment: insulin resistance and $\beta$-cell function from fasting plasma glucose and insulin concentrations in man. Diabetologia 28(7), 412-419 (1985)

26. -Hayran M., Hayran M.:Sağlık Araştırmaları İçin Temel İstatistik. Omega Araştırma, Ankara (2011)

27. S.O. Nomura, L. Harnack, K. Robien, Estimating bisphenol A exposure levels using a questionnaire targeting known sources of exposure. Public Health Nutr. 19(4), 593-606 (2016)

28. G.F. Giesbrecht, J. Liu, M. Ejaredar, D. Dewey, N. Letourneau, T. Campbell, J.W. Martin, APrON Study Team: urinary bisphenol a is associated with dysregulation of hpa-axis function in pregnant women: findings from the apron cohort study. Environ. Res. 151, 689-697 (2016)

29. J.S. Siracusa, L. Yin, E. Measel, S. Liang, X. Yu, Effects of bisphenol A and its analogs on reproductive health: a mini review. Reprod. Toxicol. 79, 96-123 (2018)

30. A. Shafei, M.M. Ramzy, A.I. Hegazy, A.K. Husseny, U.G. ElHadary, M.M. Taha, A.A. Mosa, The molecular mechanisms of action of the endocrine disrupting chemical bisphenol $\mathrm{A}$ in the development of cancer. Gene 647, 235-243 (2018)

31. S. Medwid, H. Guan, K. Yang, Bisphenol A stimulates adrenal cortical cell proliferation via ER $\beta$-mediated activation of the sonic hedgehog signalling pathway. J. Steroid. Biochem. Mol. Biol. 178, 254-262 (2018)

32. S. Barutçu, M.M. Tuna, F. Kılınç, Z. Pekkolay, H. Soylu, A.K. Tuzcu, Non functioning adrenal incidentalomas may be associated with insulin resistance/ Nonfonksiyonel adrenal insidentaloma insülin direnci ile ilişkili olabilir. J. Clin. Exp. Investig./Klin. ve Deney. Arastirmalar Derg. 5(4), 589-592 (2014)

33. M. Peppa, E. Boutati, C. Koliaki, N. Papaefstathiou, E. Garoflos, T. Economopoulos, D. Hadjidakis, S.A. Raptis, Insulin resistance and metabolic syndrome in patients with nonfunctioning adrenal incidentalomas: a cause-effect relationship? Metabolism 59(10), 1435-1441 (2010)

34. H. Masuno, T. Kidani, K. Sekiya, K. Sakayama, T. Shiosaka, H. Yamamoto, K. Honda, Bisphenol A in combination with insulin can accelerate the conversion of 3T3-L1 fibroblasts to adipocytes. J. Lipid Res. 43(5), 676-684 (2002)

35. T. Wang, M. Li, B. Chen, M. Xu, Y. Xu, Y. Huang, J. Lu, Y. Chen, W. Wang, X. Li, Y. Liu, Y. Bi, S. Lai, G. Ning, Urinary bisphenol A (BPA) concentration associates with obesity and insulin resistance. J. Clin. Endocrinol. Metab. 97(2), E223-E227 (2012)

36. N. Jalal, A.R. Surendranath, J.L. Pathak, S. Yu, C.Y. Chung, Bisphenol A (BPA) the mighty and the mutagenic. Toxicol. Rep. 5, 76-84 (2018) 